\title{
Using Longitude on Early Nineteenth Century Voyages to Hudson Bay
}

\section{William Glover}

\begin{abstract}
Pendant une bonne partie du 19e siècle, les capitaines des navires de la Compagnie de la Baie d'Hudson déterminaient toujours leur longitude au moyen d'un compte rendu ou par navigation à l'estime lors de leurs expéditions commerciales annuelles dans la baie d'Hudson. Pourquoi ne vérifiaient-ils pas leurs résultats à l'aide de la longitude calculée par la méthode des distances lunaires, mise au point au cours des années 1760, ou par chronomètre, une pratique courante dans la Compagnie britannique des Indes orientales dès 1791? Ne croyaient-ils pas que ces nouvelles méthodes présentaient certains avantages? Pourquoi, en fin de compte, les capitaines les ont-ils adoptées? Un examen des journaux de bord des navires et d'autres documents dans les archives de la Compagnie de la Baie d'Hudson propose des idées intéressantes.
\end{abstract}

In the 1800s, what was the utility of the ability to find longitude at sea for masters of the Hudson's Bay Company (HBC) ships on the annual voyages to Hudson Bay? As the century opened, no HBC master recorded anything other than longitude by account (based on their dead reckoning from a point of departure) although the lunar distance method of observing for longitude had been developed in the 1760s, and by 1791 a chronometer longitude was common in the East India Company ships. From 1834, the masters making the voyage to the bay regularly used a chronometer to determine longitude. Why did they finally adopt other methods of determining longitude? A review of the ships' logs and other documents in the

The Northern Mariner/Le marin du nord, XXVII, No. 4 (Oct. 2017), 355-72. 
archives of the Hudson's Bay Company, the fur trading company chartered in 1670, offers some interesting suggestions. ${ }^{1}$

The 1814 resupply and trading voyage is a useful departure fix for the changes in navigation and hydrographic information that evolved over the ensuing years. In that year HMS Rosamund escorted the HBC ships on their annual voyage to the posts in Hudson Bay. Lieutenant Edward Chappell, one of her officers, later published an account of it. ${ }^{2}$ The Admiralty had requested "that a qualified person be sent on board His Majesty's Ship Rosamund to pilot her through the [Hudson] Straits." This was done by John Davison, chief mate of the Prince of Wales, who transferred to the warship on $26 \mathrm{July}^{3}$ (He had performed the same service for HMS Brazen in 1813. ${ }^{4}$ ) Chappell wrote: "Nothing can be more incorrect than the Chart supplied by the Admiralty for the guidance of a man-of-war in Hudson's Straits: it absolutely bears no resemblance to the channel of which it is intended to be a delineation. During the time we continued in Hudson's Straits, the Rosamund was entirely piloted by a chart belonging to the chief mate of the Prince of Wales, and one of his own making." "Whatever else, this emphasizes the increasing importance to mariners of accurate charts.

That the HBC masters and their mates were certainly well experienced and able to act as pilots should not be a surprise. Stability amongst the company's ships' officers which allowed for "learning the route" had been developing since the 1720s. The company paid well which encouraged a high retention rate amongst its ships' officers. Several families were in those ranks over two or even three generations. The two masters of the HBC ships in 1814, John Turner and Henry Hanwell, had both held command since $1790,{ }^{6}$ and had sons in the service. John Turner Jr. had been a second mate since at least 1812, and in 1814 was serving in that capacity under his father. Turner's chief mate, Benjamin Bell, had been promoted second mate to Henry Hanwell in 1799, and may have been related to the Benjamin Bell who in 1796 was given an annual gratuity of $£ 10$ for his services as second mate and boatswain of Queen Charlotte. ${ }^{7}$ Henry Hanwell Jr. first appears

\footnotetext{
${ }^{1}$ My thanks to Roger Sarty, chair of the Editorial Board, who organized the peer review of this piece. Likewise my thanks to the anonymous referees. I found their comments helpful, and I hope they see the benefit.

2 Lieutenant Edward Chappell, RN, Narrative of a Voyage to Hudson's Bay in His Majesty's Ship Rosamund, 1817, (reprinted Toronto: Coles Publishing, Coles Canadiana Collection, 1970).

${ }^{3}$ London Committee minutes 25 May 1814 and 21 Dec 1814, Hudson's Bay Company Archives, (HBCA) Provincial Archives of Manitoba, Winnipeg, Reel 6, A1/50. Davison journal (chief mate Prince of Wales) entry 26 Jul 1814, HBCA, Reel 2M75 C1/782.

4 Prince of Wales log, 21 July 1813, HBCA Reel 2M74, C1/778.

${ }^{5}$ Chappell, 175-6. I have not found any record of a chart by Davison.

6 They had both been appointed chief mates in 1783. Previously Turner had served as a sloop master in the bay. Hanwell is recorded as a second mate to Joseph Richards in 1775 but possibly had earlier service as a seaman.

${ }^{7}$ London Committee minutes 13 Apr 1796, HBCA Reel 6, A1/47.
} 
as the gunner of the Prince of Wales in 1813. He was appointed chief mate to his father in 1816. Davison, who served as the pilot of Rosamund, had been in the HBC at least since 1794 when he was chief mate to Hanwell.

The practice of HBC ships' officers making charts, while perhaps not common, was certainly well established. The oldest surviving map is of the west coast of James Bay, made by a Thomas Moore in $1678 .^{8}$ A chart of Hudsons [sic] Straits from 1781, drawn by John Marley ${ }^{9}$ (a long serving mate in HBC ships), is the only surviving example of a chart of the straits. The senior Henry Hanwell made a chart of the bottom of James Bay in 1803. ${ }^{10}$

Before 1828 all the captains going to Hudson Bay recorded their longitude only "by account," or dead reckoning. ${ }^{11}$ The passage across the North Atlantic, passing just south of Cape Farewell in Greenland, did not present the hazards of navigation resulting from incorrect longitude that, for example were part of an eastbound passage across the Indian Ocean, or a westbound rounding of Cape Horn. ${ }^{12}$ Had more accurate longitudes been important, Joseph Richards, captain of the Prince Rupert, who carried William Wales and Joseph Dymond to Prince of Wales Fort in 1768 for the observation of the transit of Venus, and who assisted them in taking

${ }^{8}$ George E. Thorman, “An Early Map of James Bay,” The Beaver Outfit 291, (Spring 1961), 18 22. The map itself is in the British Library.

9 HBCA, G2/31. Although complete sets of the HBCA microfilm are available at the Library and Archives of Canada in Ottawa, and at The National Archives in Kew, London (with different reel numbers), the maps and charts are only available in Winnipeg.

10 HBCA, G2/20.

11 At the beginning of every sea voyage the master would take a "departure fix" — a range and bearing from a known point, frequently referred to as an "established position." However, that point's latitude and longitude were frequently in error. Every two hours the course made good (a combination of the course steered and leeway, the effect of the wind pushing the ship sideways) was recorded on a traverse board, along with the speed of the ship, which was determined by streaming a log. At sea the new day began at noon, which unlike midnight is an observable event. (Hence every afternoon the nautical date was ahead of the civil date.) "High noon" is the meridian passage of the sun - its highest altitude - as the sun crosses an observer's longitude. Every day the master used the traverse board information to calculate his distance and bearing from the previous day's noon position. And so an "account" was kept of the daily noon positions, all going back to the departure fix based on the established position of the known headland. Published "traverse tables" were used to convert the range and bearing information into a latitude and longitude. Without an independent means of determining longitude, only the latitude information could be checked against the noon sight of the sun. Every piece of information was subject to error. A discrepancy between the observed latitude and the latitude by account would have to be "reconciled." A more detailed explanation of this, and the HBC practice of navigation in the 1700s may be found in my "The Eighteenth Century Practice of Navigation as Recorded in the Logs of Hudson's Bay Company Ships," The Northern Mariner/Le marin du nord 26:2 (April 2016), 14564.

12 The west coast of Australia was the navigational hazard for ships crossing the Indian Ocean whose reckoning was behind their actual position. Today it is well known to wreck divers. Anson's difficulty rounding Cape Horn is probably the best known example on that route of the consequences of not knowing longitude accurately. 
lunar distances, ${ }^{13}$ would have used lunars. As it is, the use of lunars for finding longitude is not recorded in the HBC log books before the 1820s. The first chronometer to enter Hudson Bay may have been carried on board HMS Rosamund in $1814 .{ }^{14}$ On at least one occasion she shared her estimate of longitude with the HBC ships, but it does not seem to have been regarded as anything other than another source of information. ${ }^{15}$

The next appearance of a chronometer in the bay was an indirect consequence of weather, which would yet play a more forceful role. In 1815 the company's ships sent to Moose Factory at the bottom of James Bay, Eddystone, John Turner, and Hadlow, a chartered vessel with John Davison in command, had wintered over, returning in 1816. In 1816 the two HBC ships sent to the Bay were Prince of Wales, Henry Hanwell, which in 1815 had been able to get home from York Factory, and Emerald, Benjamin Bell, chartered for the trip to Moose Factory. Both were caught by ice on the return voyage and compelled to winter over in the Bay. Different ships and masters had to be found for the 1817 voyage. Turner's conduct of the 1815-16 voyage had been the subject of complaint, and he was dismissed. Therefore, for the 1817 voyage, the company had Eddystone available and appointed Davison to his first permanent command. To provide for the necessary cargo capacity the Britannia was chartered, complete with master. She carried a chronometer, and for several days her reported longitude was recorded by Davison in his $\log .{ }^{16}$ The value of this information is not now clear. On examination, it would seem that the chronometer longitudes were at least one degree west of the longitudes by account. On 23 June Davison's longitude by account was $63^{\circ} 41^{\prime} \mathrm{W}$ while Britannia's chronometer gave the longitude as $65^{\circ} 01^{\prime} \mathrm{W}$. The next day Resolution Island was sighted. Comparing his known position relative to the island, against his account, $64^{\circ} 00$ 'W, Davison

\footnotetext{
13 A lunar distance was the observed horizontal angle between the moon and (normally) the sun or perhaps a star. Ideally three observers had to take simultaneous observations of: the altitude (vertical angle above the horizon) of the moon, the altitude of the sun or star being used, and the horizontal angle between them. The local time also had to be noted. The Nautical Almanac, first published in 1767, provided tables from which the time the same observed angle had occurred at Greenwich, England, could be determined. Longitude is a measurement of time from the Greenwich meridian. When first developed the calculations to reduce the sights took about three hours. Improvements to the tables later reduced this to about half an hour. The shortcomings of lunar distance method are discussed below.

${ }^{14}$ Chappell, 177. Given both the failure of the Admiralty to ensure that Rosamund had the necessary equipment of navigating in ice, (Chappell, 19), and the observation with respect to the Royal Navy, "more and more officers were providing themselves with chronometers at their own expense," (W.E. May, "How the Chronometer Went to Sea" reprint from Antiquarian Horology: The Official Journal of the Antiquarian Horological Society, March 1976, 648), this chronometer may have been privately purchased.

15 Prince of Wales, $\log 22$ July 1814: "The convoy spoke me and enquired my longitude in at noon." HBCA, Reel 2M74, C1/781. Rosamund reported her longitude as $48^{\circ} 20^{\prime} \mathrm{W}$. Hanwell recorded his as $47^{\circ} 32^{\prime} \mathrm{W}$.

${ }^{16}$ Eddystone log entries for 19 June 1817 and following, HBCA, reel 2M23, C1/303.
} 
recorded "I find my account ahead [west] of the ship 8 leagues." 17 While Davison would have been comparing his ship's actual position in relation to Resolution as best known to him, it is important to remember that his understanding of the island's longitude was almost certainly wrong. ${ }^{18}$ As we know the position of Resolution today, the chronometer reading was more accurate than the longitude by account.

The transition of company masters to the active use of lunar distance and chronometers for determining longitude was ultimately a result of events in 1821 . The bloody competition between the HBC and its Montreal-based rival, the North West Company, was concluded with a coalition of the two companies. ${ }^{19}$ The HBC had acquired the North West Company's posts and territory west of the Rocky Mountains, beyond the original HBC grant of lands that drained into Hudson Bay. This included Fort George on the Columbia River near Astoria and the Columbia District. This region needed the same resupply and support that was provided annually to the Bay posts. Hence the company required additional shipping capacity.

In 1822 the Lively was chartered with her owner, Robert Richie, serving as master. On 3 September 1822 she was in London, "now loading for the Columbia." ${ }^{20}$ She sailed south via the Cape of Good Hope and then crossed the Atlantic. Her surviving log begins there on 1 January 1823 and ends with her return to London on 29 March $1824 .^{21}$ Richie took his departure fix from Cape of Good Hope on 4 January. He recorded chronometer longitudes on 6 and 10 January, and his first lunar observation on 18 January. Unfortunately he seldom noted his position by account in his $\log$, so comment about his methods and difficulties is limited.

His lunar observations appear to have been reasonably regular. By contrast, after 10 January, his next chronometer longitude was 20 February, and this was the last for his outbound voyage. His log gives no indication of whatever doubts or confidence he may have had in his chronometer. At 0900 on 3 March as he approached Cape Horn he "got a set of distances \& found longitude to be $66^{\circ} 39^{\prime} \mathrm{W}$. Longitude by account is $72^{\circ} 30^{\prime} \mathrm{W}$ a difference of nearly $6^{\circ}$ which is in consequence of the strong current setting eastward.'This he addressed at his first opportunity by

\footnotetext{
17 Eddystone log 24 June 1817, ibid.

18 The modern value for Hatton Headland, the southeast extremity, is $64^{\circ} 47^{\prime} \mathrm{W}$. Three years after Davison's entry, the $1820 \mathrm{HBC}$ chart shows it at $65^{\circ} 10^{\prime} \mathrm{W}$. Also in 1820 , Davison worked the longitude of Resolution as $65^{\circ} 05^{\prime} \mathrm{W}$ (Prince of Wales log entry 27 September, HBCA reel 2M76, C1/791).

19 The HBC shareholders approved the terms on 26 March 1821. The agreement for the trade was to take effect from 1 June 1821. Parliament adopted the necessary legislation in July.

${ }^{20}$ Minutes of the Board to Consult and Advise on the Management of Trade, HBCA, Reel 20, $\mathrm{A} / 3 / 1$

${ }^{21}$ Lively log, title page, HBCA, Reel 2M46, C1/452.
} 
taking a new departure. On 5 March "At 1 [nautical date; civil date and time was 1300 on 4 March] saw the Isle of Diego Ramirez (situated about eleven leagues south of Cape Horn) SW 3 leagues. At 2:30 the west end of Diego Ramirez bore SSE 2 leagues from which I take my departure in Latitude $56^{\circ} 27$ 'S Longitude $68^{\circ} 39^{\prime} \mathrm{W}$." The next morning at 1000 (that half day when civil and nautical date are the same) he took a lunar distance. As his position for Diego Ramirez (probably from a chart) varies from the modern values only by $13^{\prime}$ longitude (too far east) his lunar longitude, $71^{\circ} 03^{\prime} \mathrm{W}$, must have been in error. ${ }^{22}$

As Richie sailed north his next landfall was on Robinson Crusoe Island ( $\mathrm{W}^{1 / 2} \mathrm{~N}$ 11 leagues) of the Juan Fernandez Islands. ${ }^{23}$ His record of the longitude, again probably from a chart, was 45' east. One week later on 31 March he entered in the $\log$, "Midnight the Isle of St Ambrose NE 7 leagues in lat $26^{\circ} \mathrm{S}$ " and at 0330, "the Isle of St Felix EbyN 3 leagues." At 0500 he concluded, "This must be a mistake or the Arrowsmith chart is wrong." Finally at noon his observed latitude was $25^{\circ} 30^{\prime} \mathrm{S}^{24}$ As the modern values for the latitudes of those islands are $26^{\circ} 28^{\prime} \mathrm{S}$ and $26^{\circ} 23$ 'S, the chart was certainly in error by the respective number of minutes, but to have made fifty-three miles straight north [for a minute of latitude is one nautical mile] between 0300 and noon may also suggest an observation error.

The final opportunity to assess Richie's position information comes from his $\log$ entries of 16 June. At 1340 he had a lunar distance longitude of $125^{\circ} 19^{\prime} 15^{\prime \prime} \mathrm{W}$; at 1800 he "saw New Albion coast." The next morning at 0900 his longitude by account was $122^{\circ} 08^{\prime} \mathrm{W}$ and at noon his latitude was $38^{\circ} 40^{\prime} \mathrm{N}$. That put him north of San Francisco; his longitude by account would have had him inland only a few miles west of Sacramento! After a good lunar longitude on 14 July, the next day he safely crossed the bar of the Columbia River, and anchored at Fort George. All this emphasizes that at any time, any particular component of position information could be wrong. That a lunar longitude, for example, was accurate one day was no guarantee that the next observation would be as well. Navigation relative to land in sight, regardless of position estimates, at least had some certainty.

While Richie was away the London Committee had to make arrangements for the 1823 voyage. The Vigilant, Captain James Davidson, was chartered. ${ }^{25}$ However no records seem to have survived. For the 1824 voyage, rather than chartering a ship, on 20 May, the HBC bought the William and Ann. Henry Hanwell, who had

\footnotetext{
Ibid., entries 3 and 5 March 1823.

Ibid., 24 March 1823.

24 Ibid., 31 March 1823.

${ }^{25}$ London Committee minutes, 22 and 29 October1823, reel 7, A1/53.
} 
already been appointed as the chief mate of the Camden destined for Moose Factory, was appointed to the new command one week later. ${ }^{26}$

On 31 July Hanwell took his departure from the Lizard, "NEbyE 7 or 8 leagues" as he started on his voyage. His longitudes by account and chronometer, $15^{\prime}$ and 30' respectively farther west of the Lizard longitude, must both be considered reasonable, given the approximate nature of the range and bearing from the headland. He stopped at Madeira 10-13 August. On sailing from Madeira, the differences between his longitude by account and chronometer went from being very close (25 August) to, just four days later, the account being nearly $2^{\circ}$ to the west. On 2 September he "spoke" with a vessel out of Philadelphia bound for Valparaiso. The reported longitude of the American ship was only 7' east of his chronometer longitude and $2^{\circ}$ east of his account. His first lunar distance longitude on 14 September was 30' east of his account, with the chronometer longitude almost exactly in the middle. The 17 September log recorded a range from the lunar to the chronometer longitudes of almost a degree. The next day the lunar longitude was $3^{\prime}$ west of the account, and just 35' east of the chronometer. ${ }^{27}$ In other words, rather than having consistency, Hanwell had to reconcile the uncertainty of his longitude information.

On 26 September Hanwell sighted Cape Frio, approximately sixty nautical miles east of Rio de Janeiro. He somehow determined that the "Chronometer increase of loss on Greenwich time [is] 3 secs." He also noted in his log, "from the state of the vessel forward and to get water with the wish to get the water stowed in the hold without opening the main hatch I determined to proceed to Rio de Janeiro." He arrived there on 28 September. ${ }^{28}$

On 14 October he sailed from Rio de Janeiro. As the voyage continued down around Cape Horn and then north along the Americas, so too did the variable relationship of longitude information by account, chronometer and lunar distance. Two weeks out of Rio de Janeiro, his longitude by account had been $1^{\circ} 30^{\prime}$ west of his chronometer for several days. In the first week of November the lunar longitudes confirmed the account. After he rounded the Horn, (about 11 November), the longitude by account opened gradually to be more than $6^{\circ}$ west of the chronometer. A lunar distance on 1 December was only 50' west of the chronometer. Landfall on

\footnotetext{
${ }^{26}$ London Committee minutes, 26 May 1824, HBCA, Reel 7, A1/54. His mate, John P. Swan, who would succeed him in that command, does not appear to have had previous employment with the HBC.

27 William and Ann log entries, HBCA, reel 2M129, C1/1066.

${ }_{28}$ Hanwell's voyage may warrant a footnote in BC regional history because of that port visit. John Walbran, in his classic work on BC coast names, says that William Brotchie, for whom Brotchie Ledge is named, first appeared in the books of HBC ships in 1831. This has been repeated as recently as The Encyclopedia of Raincoast Place Names, (Madeira Park, BC: Harbour Publishing, 2009). Hanwell noted in his log on 6 October 1824, while in Rio de Janeiro, "engaged William Brotchie as a seaman this day." HBCA, Reel 2M129, C1/1066.
} 
the Juan Fernandez Islands provided a much needed check. After sighting land on 17 December, Hanwell concluded that chronometer was $1^{\circ} 15^{\prime}$ east of the ship. But when he anchored in Cumberland Bay, Robinson Crusoe Island, his chronometer gave a longitude only 30' east of the current value. Hanwell may have used an incorrect chart longitude to assess his chronometer.

As the ship continued north, on 2 and 3 January Hanwell recorded lunar distance longitudes based on the moon and Venus. For the first, the account, chronometer and lunar longitudes were within $1^{\circ}$, and for the second only $34^{\prime}$ part. North of the Galapagos Islands the William and Ann probably began to experience an unrecognized current. ${ }^{29}$ On 18 January Hanwell noted, "Lat from last obs [noon 17 January] $3^{\circ} 15^{\prime}$. Noon obs $4^{\circ} 17^{\prime}$. Account $3^{\circ} 08^{\prime}$. $69^{\prime} \mathrm{N}$ of account since last obs and $2^{\circ} 29^{\prime} \mathrm{W}$ in four days." ${ }^{30}$ On 5 February a lunar with the moon and the star Pollux gave a longitude only $10^{\prime}$ off his chronometer. The account was more than $1^{\circ}$ to the east, and over the next two weeks it varied, sometimes nearly $3^{\circ}$ east. On 22 February Hanwell decided to run a new account from his chronometer longitude and observed latitude of the previous day.

Throughout most of March Hanwell experienced heavy gales. On the $3^{\text {rd }}$ he wrote, "During these heavy gales I have endeavoured to keep well off land. Columbia River is today by Long Chr and the obs lat at N63E by chart 170 leagues. " Three days later he added, "Having so much bad weather I thought it proper for our safety to endeavour to keep to the westward to wait for an opportunity of running for the Colombia River. Lat from yesterday's obs $45^{\circ} 02^{\prime} \mathrm{N}$." This was prudent; the Washington/Oregon coast, (the river is the state boundary), is frequently steep to, with few places for shelter on a lee shore. The entrance to the Columbia, against a strong river current that may be confused with a flooding tide, over a shifting sand bar, when coupled with a heavy sea from the west is one of the most dangerous on the coast. Still to seaward, on 1 April he concluded, "Chron to eastward of the ship $1^{\circ} 4^{\prime}$." On 12 April he safely anchored off Fort George.

Like Richie before him, Hanwell always had to assess the position information available to him at any given time. No one component had a better track record of consistency and accuracy.

In 1825 the Dryad was chartered for the voyage. Her master was characterised as a "grog drinker" 31 and when the ship was purchased by the company, he did not continue with the HBC service. ${ }^{32}$ Hanwell and the William and Ann arrived back in

\footnotetext{
${ }^{29}$ Matthew Fountaine Maury,USN, would not begin his fundamental work on wind and current charts for another twenty years.

30 William and Ann log entries.

31 E.E. Rich, Hudson's Bay Company 1670 - 1870, vol 2, “1763 - 1870, (London: Hudson’s Bay Record Society, 1959), 613.

${ }^{32}$ Dryad's log is not part of the HBCA collection, and is at The National Archives in Kew, London.
} 
London on 15 April 1826. Hanwell made a second voyage in her to the Pacific, departing in September with the schooner Cadboro in company. Fifty-six feet overall and displacing seventy-one tons, she was to remain on the coast as a trading vessel. John Swan, who had been mate to Hanwell in William and Ann, was the delivery master. Swan carefully took lunar distances for his longitude, including observations between the moon and stars. ${ }^{33}$ He does not appear to have had a chronometer. Swan returned to England as the mate for Hanwell, and succeeded him in command of the William and Ann for the 1828 voyage. She was lost in 1829 with all hands on the Columbia Bar. For the 1827 voyage the HBC found the brig Eagle, with her master John Costello Grave. On 18 October, off Madeira, he noted that the chronometer corresponded exactly with the land. Rounding the Horn he took six lunar distances, one of which was with a star. ${ }^{34}$ Grave remained in Eagle through $1832 .^{35}$

The voyages to Hudson Bay had been continuing without resort to lunar distances or chronometers for longitudes. On 13 February 1828 Hanwell "was introduced [to the London committee] on his return from the Columbia River." The following week the committee "resolved in consequence of Captain Davison's age and infirmities that he be removed from the command of the ship Prince of Wales and allowed one hundred pounds a year during the pleasure of the governor and committee." Then, on 23 April the committee appointed Hanwell in Davison's place to command of the Prince of Wales. ${ }^{36}$ So the HBC appointed to its bay route the first master with demonstrated use of chronometers and lunar distances for determining longitude.

The ships' logs over the next few years suggest that very little changed with respect to the use of longitude. The various logs kept by Benjamin Bell of Prince Rupert and his mates do not show any evidence of the use of lunar distances let alone a chronometer. Longitude by account was clearly deemed sufficient. On Hanwell's first Bay voyage in command, he recorded five lunar distance observations between sailing from Stromness and sighting Resolution. Interestingly, in addition to an account based on his departure fix from the Orkneys, he seems to have run a second account from his lunar distance longitudes. His chief mate, Thomas Terry, specifically identified his longitudes as being from London, although the nautical almanac tables used for a lunar distance were calculated from Greenwich. Perhaps the 5' difference of longitude between Greenwich and St Paul's, the customary datum for London, were thought to be of no significance. Given the combination of other errors, that would not have been a major mistake.

\footnotetext{
33 Cadboro log entry 17 May 1827, HBCA, reel 2M2, C1/217.

${ }^{34}$ Eagle log entries, HBCA, reel 2M19, C1/283.

35 Unfortunately his later Eagle logs do not survive. In 1833 W. Darby was appointed to Eagle in command.

${ }^{36}$ London Committee minutes, HBCA, reel 7, A1/56.
} 


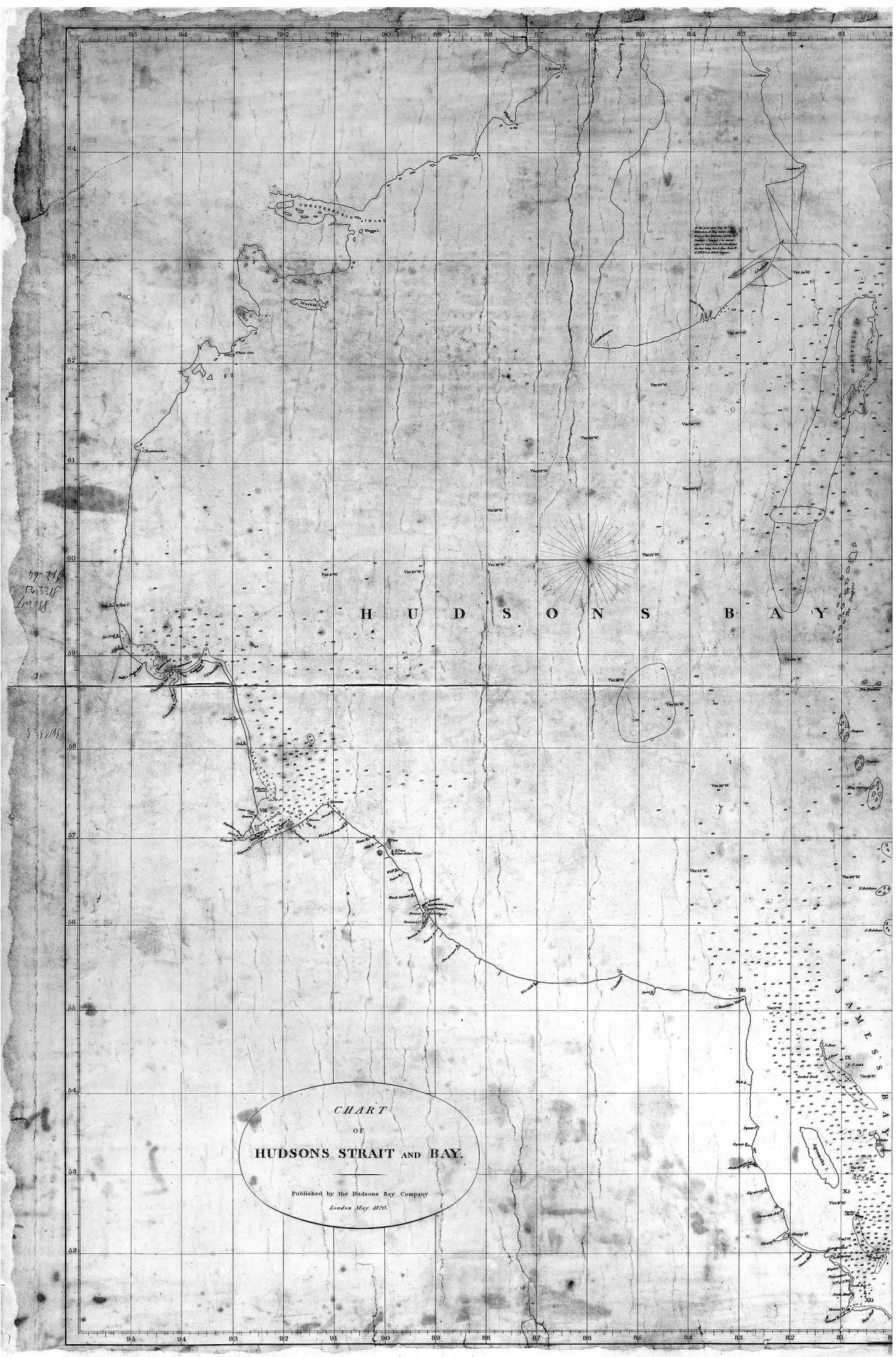




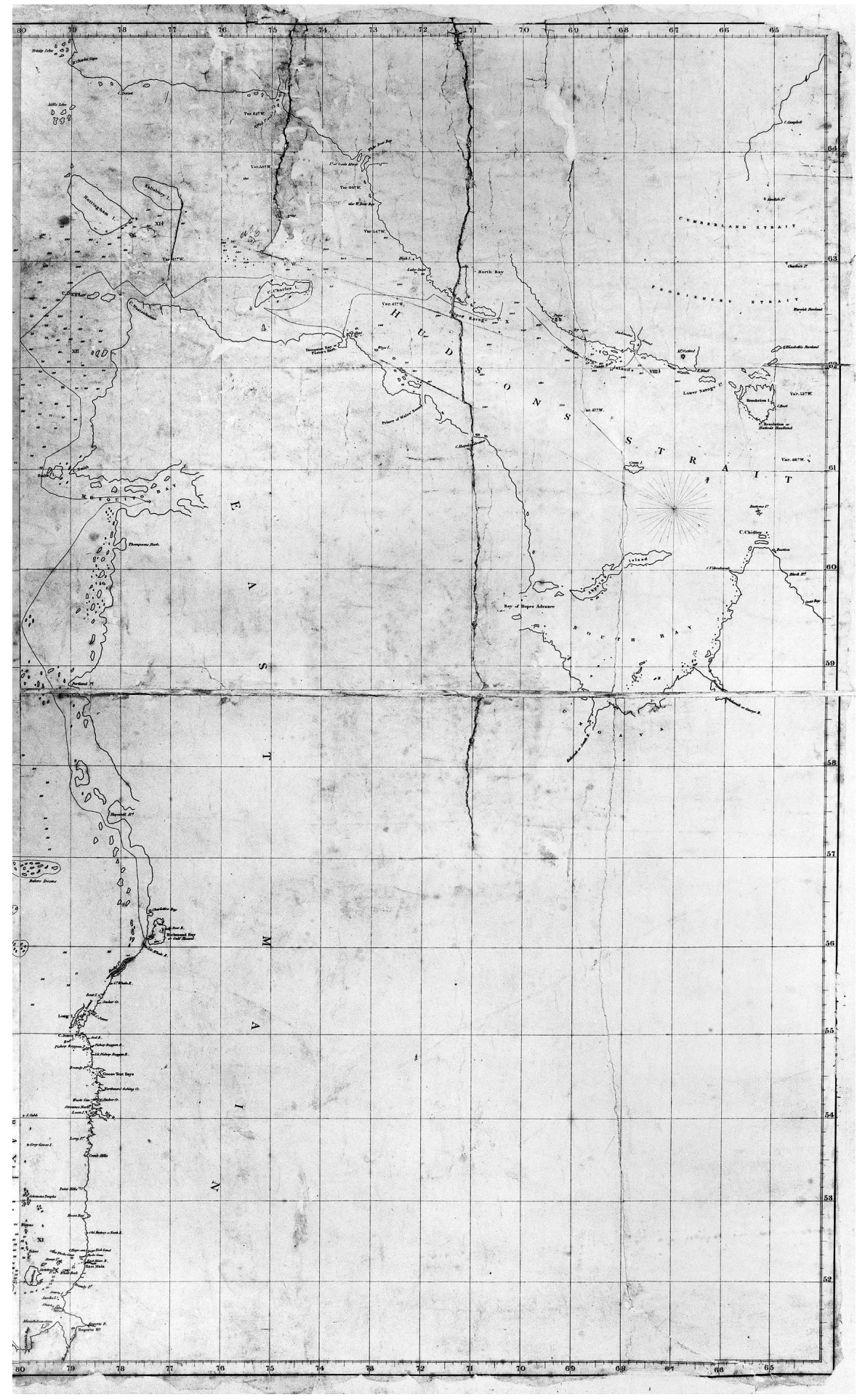


In 1829 , on the homeward bound passage, Hanwell confidently recorded a longitude based on soundings when he was one day out from the Lizard. ${ }^{37}$ Throughout the voyage he clearly identified longitudes by lunar distance, but no chronometer longitude is so identified. By contrast, on 12 August, Terry, the chief mate did a few. But he continued to use "longitude in from London." Finally in 1830 Hanwell recorded both lunar and chronometer longitudes. That voyage Hanwell was forced to winter over, returning to London in 1831 . His log for 1832 has not survived.

Meanwhile during these years the was an important addition to the ranks of HBC masters. In 1829 a need for additional capacity had led to the chartering of the Montcalm for the voyage to the Bay to York Factory. The agreement obviously included the master, who was Robert Royal. She also made the 1830 voyage under similar arrangements. ${ }^{38}$ In 1831 Royal transferred to the HBC service as the master of the Camden. ${ }^{39}$ The Montcalm logs do not survive, so the 1831 Camden log offers the first indication of Royal's qualitites. On departure from Stromness he was recording his longitude by chronometer from Greenwich! ${ }^{40}$ In 1832 Royal was appointed to the Ganymede for a voyage to the Columbia. He arrived back at London on 1 March 1834.

Weather struck the 1833 voyage to the Bay with a tragic fury. The two ships, Prince Rupert, Benjamin Bell, and Prince of Wales, Henry Hanwell, were forced back by ice in Hudson Strait as they began their return voyage and had to winter in the Bay. The Prince Rupert went to Churchill, and the Prince of Wales went to Charlton island. (Thomas James had determined a longitude while wintering there in 1631.) Of the Prince of Wales officers, Hanwell died on 1 April 1834, and Thomas Terry, the first mate, died on 26 April. Henry Baker, the second mate, succeeded to command, and appointed Charles Humpreys as first mate and Edward Reeder as second mate. ${ }^{41}$ At Churchill, Benjamin Bell, master of the Prince Rupert, was severely incapacitated by illness. John Mannock, the first mate, had died "by apoplexy" on 1 October and Edward Bailes had been appointed in his place. Therefore after the breakup, it was Bailes, acting in command, who took the ship down to York Factory.

In London, the failure of the ships to return by the end of November 1833 was a harbinger of the bad news. In January and February letters from Moose Factory sent overland through New York confirmed the worst. ${ }^{42}$ For the 1834 supply voyage the committee sent Robert Royal in Ganymede, recently returned from the

\footnotetext{
37 Prince of Wales log entry 22 October 1829, HBCA, reel 2M81, C1/818.

${ }^{38}$ London Committee minutes, 4 February 1829, 21 April 1830, HBCA, reel 8, A1/57.

39 London Committee minutes 4 May 1831, HBCA, reel 8, A1/57, "Capt Robert Royal to the Camden with William Wild as chief mate."

40 Camden log entry 3 July 1831, HBCS, reel 2M5, C1/231.

${ }^{41}$ Henry Baker, (second mate, Prince of Wales), journal, f2 \& 3, HBCA, Reel 2M82, C1/826.

${ }^{42}$ London Committee minutes, 15 January and 5 February 1834, HBCA, reel 8, A1/58.
} 
Columbia, and a new ship, Prince George. This command was given to Grave, last employed in the Eagle on the Columbia voyage. Royal was sent to Moose Factory, and Grave went to York Factory. On the outbound voyage both masters recorded longitudes by chronometer, and neither appears to have taken lunar distances.

On arrival at York, on 22 August, Grave went on board the Prince Rupert where he found Captain Bell "very infirm having lost the use of both legs and left hand, unable to move without assistance." Three days later he returned on board to assume command. ${ }^{43}$ Daniel Friend took command of the Prince George for the return passage. Grave took the chronometer with him to his new ship. This suggests that it may have been personal property rather than provided to a ship as part of the equipment. $^{44}$

Going forward from 1834 the existing masters and the mates who were subsequently promoted to command all had experience with using chronometers for longitude or working a lunar distance. Why had the adoption of chronometers been slow by comparison with the practice on other British shipping routes ${ }^{45}$

The simple reason is that the level of accuracy it provided over longitude of account, (and as the Richie and Hanwell Jr. voyages around to Horn were to show, the improvement was uncertain), was of no value to them. Changes of longitude gave an estimate of east/west distance made good. Longitude by account was sufficient to give the master an expectation of when to see land. On the Hudson Bay voyage the unexpected sighting of land did not constitute a danger, as the west coast of Australia did, or even the Columbia River entrance. But beyond that, their charts did not accommodate the use of longitude.

Given Chappell's comments about the charts available to HMS Rosamund, what charts were there for the HBC masters? The first printed chart (as distinct from earlier manuscript charts) of a size useful for navigation that I have found in the HBC archives, appears to be of 1820 (Map 1, pp. 364-65). It is indeed splendid. Published in two sheets divided at $80^{\circ} \mathrm{W}$, it must have been a compilation of information from various sources. It was probably drawn by Arrowsmith; certainly there are some commonalities between it and his 1809 "Chart of Labrador and Greenland." 46 It has two thirty-two point compass roses and soundings in the HBC

\footnotetext{
43 Prince George/Prince Rupert log, entries 22 and 25 August 1834, HBCA, reel 2M66, C1/735.

${ }^{44}$ This would be consistent with what appears to have been the practice of the day. In the $1780 \mathrm{~s}$ East India Company captains bought their own chronometers. (Alun C. Davies, "Vancouver's Chronometers" in Robin Fisher and Hugh Johnston, eds., From Maps to Metaphors, (Vancouver: UBC Press, 1993) 74).

45 Davies, 70.

46 British Library, Maps 70915.(1.). Whatever the chart was that was issued to Rosamund, given Chappell's comments iy is unlikely to have been this one by Arrowsmith. Given its similarity to the 1820 chart, and Arrowsmith's working relationship with the HBC, it most certainly would have reflected the best information of the HBC masters. The charts issued to the Royal Navy ships had been a concern in the early 1800 s.
} 
high traffic areas. It has tidal information and spot magnetic variations. But it does not indicate the reference for the longitude-Greenwich or London. Other difficulties are evident on a closer examination.

In a comparison of James Bay and the Quebec coast north of James Bay (Map 2), two things are instantly apparent. First, the Quebec coastline is wrong. The longitudes do not reflect the gentle east-trending curve. A more serious shortcoming is that the islands are generally wrong. This is important because the masters would frequently record taking a departure from one of them. Therefore their longitudes by account within the Bay would have been wrong. But, like the difference between St Paul's Cathedral and the Greenwich observatory, the margin of error may not have been significant.

In the northern part of the Bay and the western entrance to the strait (Map 3), there are 5003 problems with the land forms.

But as the HBC ships were passing them, that probably was not a major concern. A more important difficulty was the error of longitude. The modern chart has $80^{\circ} \mathrm{W}$ slicing Mansell Island west of the midpoint, whereas on the HBC chart what is called Mansfield Island is well to the west of the meridian. This gives the east coast a longitude of about $80^{\circ} 20^{\prime} \mathrm{W}$, only $8^{\prime}$ east of the 1781 Marley position of Mansfield. The error for the eastern shore of the island is in excess of one degree from the modern value. That would have impacted a departure fix based on the 


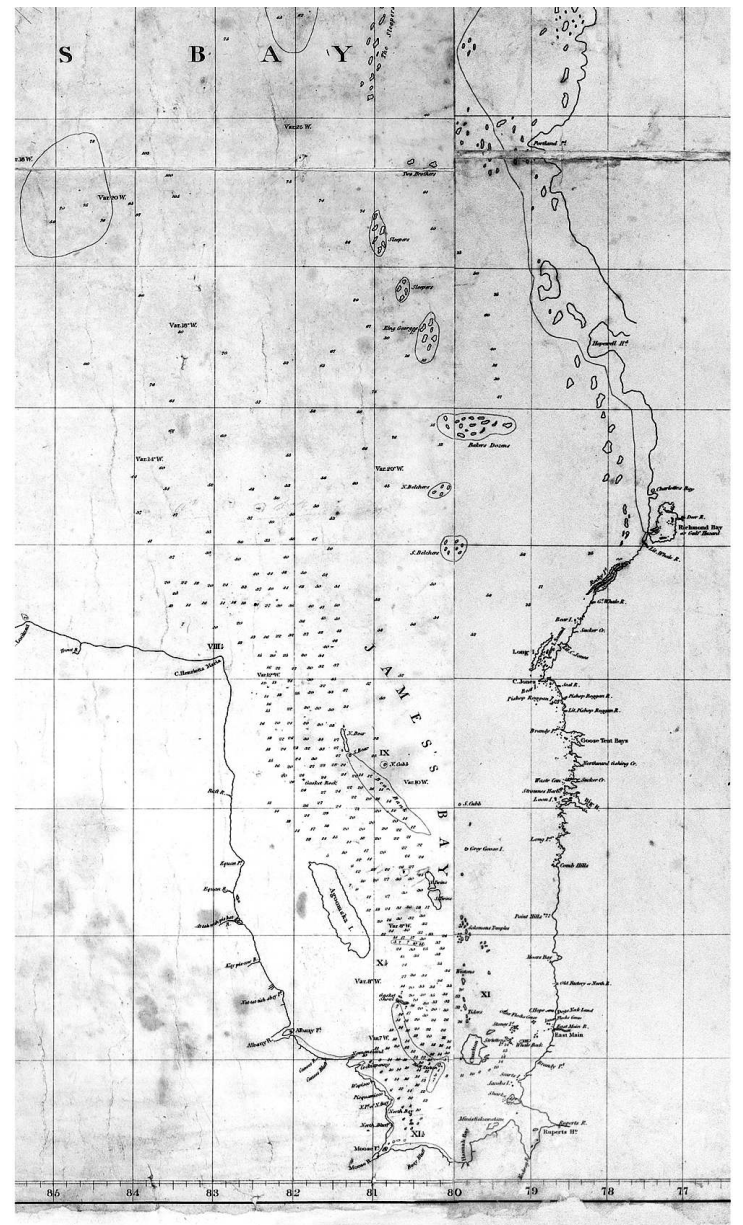

island. The chart's longitude error is not consistent however, which only serves to complicate things. The error for the southeast bluff of Resolution is only 23'.

Perhaps the more interesting error is that Resolution is approximately 10' too far north. Observations for latitude were straight forward, and accuracy within 5' could be expected. By contrast, the Marley 1781, Arrowsmith 1809 and the HBC chart 1820 longitudes had a range of 16 '.

Although by modern standard the 1820 chart had numerous errors, it must be remembered that by contemporary standards, it was accurate. Therefore one might ask, why did the HBC masters not adopt the then current methods of finding longitude rather than relying on their accounts? The answer may be found in the nature of coastal and pilotage navigation. It is important to understand that the concept of position as a precise spot was not then developed. In the twenty-first century we talk of precise navigation; a hand held GPS device will give different readings for the extremities of a ship. This is a development of accuracy from positional navigation, where a navigator using either a three point visual fix, an observed astronomical position or even a radio fixing aid, could easily determine the position of the ship to a pencil width's accuracy. That in turn was a function of the scale of the chart on which the position was plotted. But in the nineteenth century, coastal and pilotage navigation was still heavily dependant on relative positions. When in sight of land the navigator knew where the ship was relative to the destination or (one hoped) the hazards. Perhaps the most famous and graphic example of this was the "aim to miss" practice after the opening of the Suez Canal. If one deliberately steered east or west of the Mediterranean entrance, one knew which way to head for the canal on sighting land. The exact position information of both the ship and the points on land were not as important. 


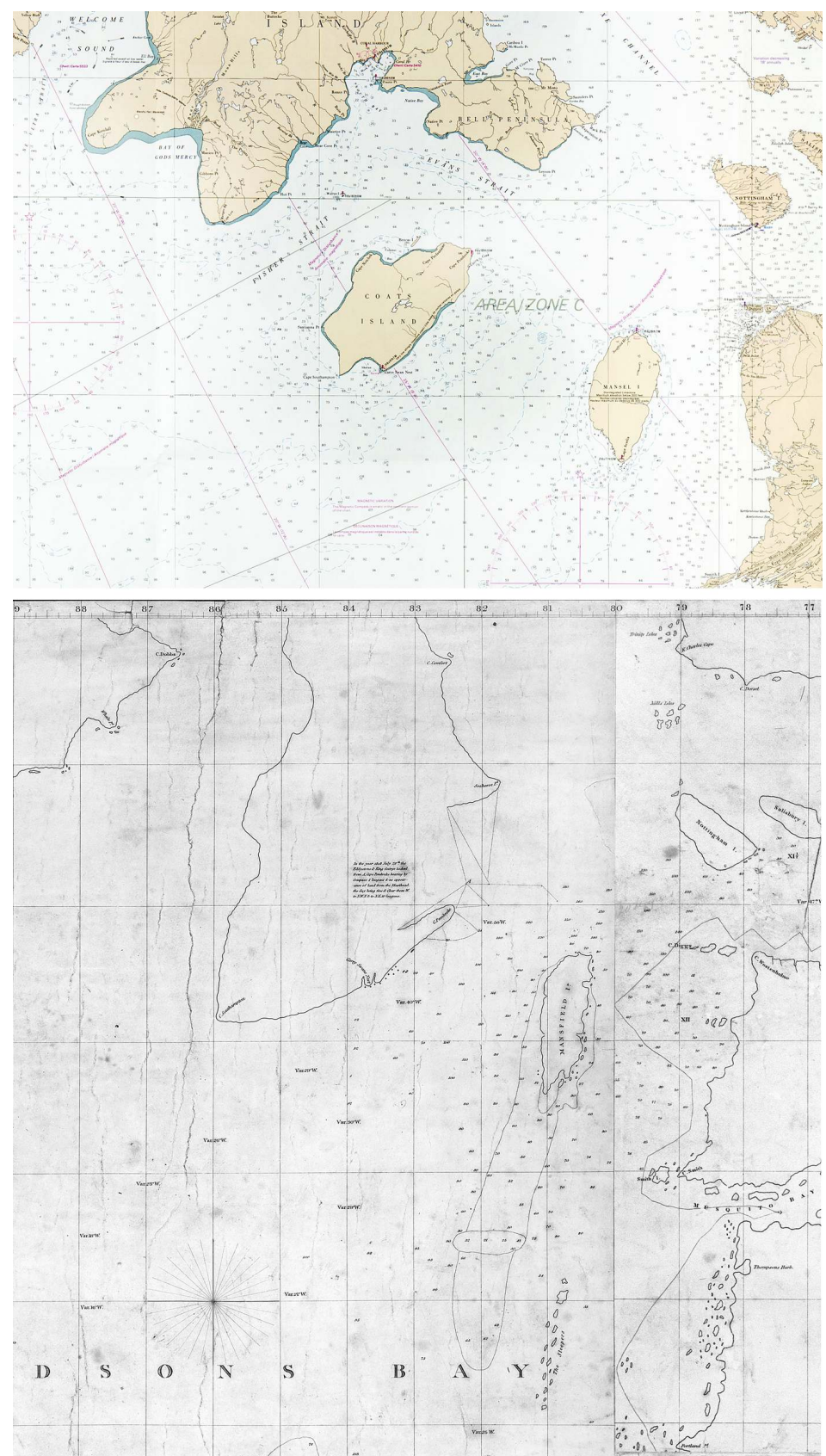

Map 3: Comparison of the western entrance to Hudson Strait: Detail from G3/154 and G3/155 compared with detail from "Hudson Bay - Northern Portion," (Ottawa: Canadian Hydrographic Service, 1986) chart 5449. 
The safety record of the 1820 masters, and of their predecessors was ample evidence that their practice of navigation was perfectly acceptable. What were the obstacles or costs to improve it?

The observation of lunar distances was neither an easy nor accurate method of determining longitude. As a sextant cannot measure an angle greater than $120^{\circ}$, the sun and moon must be within that distance, something that does not occur more than half the days of a month. When it was possible, weather could preclude an observation. A lunar distance between the moon and a planet or star is possible if it is dark enough to see the star, while still bright enough to see the horizon. An observation error of 10"in the lunar distance would mean an error of $5^{\prime}$ in the calculated longitude. ${ }^{47}$ That level of accuracy required a very skilled observer. An astronomer royal of the early twentieth century has noted, "unfortunately even with perfect tables, it is found that the most skilful navigator cannot obtain a very accurate position of his ship in this manner. With great pains and somewhat elaborate calculation, he can be correct to within twenty miles." 48 But in the early 1800 s the perfect tables did not yet exist. As Captain Lecky observed when first writing in 1881, "an additional error of 6' to 8' due to a small uncertainty still existing in the place of the moon as given in the tables" was an additional error. ${ }^{49}$ Lieutenant Raper's Practice of Navigation, first published in 1840, had the following qualification: "A single observation however is not capable of affording a decisive result; great practice is necessary for measuring the distance successfully; and the application of so many small corrections as are necessary when accuracy is required is, even with extraordinary care and some skill, scarcely compatible with extreme precision." "50 Richie twice recorded taking "sets" of observations. Hanwell's lunar longitude was frequently sufficiently different from the account and chronometer longitudes that he had to make his own assessment. On the comparatively straight forward North Atlantic crossing to or from Hudson Bay, it cannot be surprising that lunars had not been used.

For determining longitude by chronometer, to state the obvious, first the captain had to have a chronometer. The decision to buy one would doubtless have been made in part with an assessment of "the return on investment." How hazardous was the voyage, and therefore how important was the information, when measured against the cost. The safety record of the HBC voyages to Hudson Bay, from the development of lunar distances and the invention of the chronometer through the

\footnotetext{
47 S.T.S. Lecky, Wrinkles in Practical Navigation, (London: George Philip \& Son, Ltd., 1915), 458.

48 Sir Frank Watson Dyson, October 1922, foreword to Lieutenant Commander Rupert T. Gould, The Marine Chronometer Its History and Development, (first published London, 1923: Antique Collectors, Club edition, Woodbridge, Suffolk, 2013), ii.

${ }^{49}$ Lecky, ibid.

${ }^{50}$ Henry Raper, The Practice of Navigation and Nautical Astronomy, nineteenth edition, (London: J.D. Potter, 1896), 302.
} 
1840s was impressive. When in 1774 Larcum Kendall made K3, the first "cheap" chronometer, he sold it to the Board of Longitude for $£ 100$. In 1791 John Arnold sold chronometers for $£ 84 .{ }^{51}$ In 1770 the HBC had approved a new pay scale for their captains of $£ 144$ a year with a gratuity of $£ 100$ if they completed the return voyage in the same season. In 1802 this had increased for the junior captain to $£ 180$ plus a $£ 50$ gratuity ${ }^{52}$ By 1842 the price of a chronometer had dropped to " $£ 40$ or less, " ${ }^{33}$ while the ships' officers' salaries had increased. Officers expected to buy their own equipment ${ }^{54}$ would have considered their need for a chronometer in relation to its cost, their salary, and the routes they sailed. The 1820 chart would not support the additional accuracy of a chronometer when the navigation hazards were not there to require it.

As result of the ships wintering over in 1833 and the subsequent deaths, the company lost all its officers serving on the Hudson Bay route. The new officers brought with them their practices developed on other routes.

${ }^{51}$ Davies, $72,75$.

${ }^{52}$ London Committee minutes 22 February 1770, HBCA, Reel 17, A1/139; minute 7 April 1802, HBCA, Reel 6, A1/48.

${ }^{53}$ Davies, 71.

${ }^{54}$ The HBC charged Peter Fidler for the books and instruments they sent to him that he needed for his work as the company's surveyor in North America. Richard Ruggles, "Hudson's Bay Company Mapping" in Carol M. Judd and Arthur J. Ray, eds., Old Trails and New Directions, (Toronto: U of T Press, 1980), 31. 